\title{
The influence of the development of the region and the level of education on the quality of life of the population
}

\section{A influência do desenvolvimento da região e do nível de educação na qualidade de vida da população}

\section{La influencia del desarrollo de la región y el nivel de educación en la calidad de vida de la población}

\author{
Lyubov Morozova1 ${ }^{\text {iD }}$, Elena Karpova² iD, Olga Kolosova ${ }^{3}$ iD, \\ Olga Kulikova $^{3}$ iD, Tatyana Suvorova ${ }^{5}$ iD
}

\author{
${ }^{1}$ Russian State University of Tourism and Service, Moscow, Russia. \\ ${ }^{2}$ Kosygin State University of Russia, Moscow, Russia. \\ ${ }^{3}$ State University of Management, Moscow, Russia. \\ ${ }^{4}$ Moscow University for Industry and Finance «Synergy» (Synergy University), Moscow, Russia. \\ Corresponding author: \\ Lyubov Morozova \\ Email: lyubov.s.morozova@mail.ru
}

How to cite: Morozova, L., Karpova, E., Kolosova, O., Kulikova, O., \& Suvorova, T. (2022). The influence of the development of the region and the level of education on the quality of life of the population. Revista Tempos $e$ Espaços em Educação, 14(33), e17222. http://dx.doi.org/10.20952/revtee.v14i33.17222

\begin{abstract}
The systematic modernization of the national economy carried out in the last 20-25 years has contributed to the formation of new socio-economic conditions in which the main criterion for the economic development of the country is the high quality of life of the population. It is the quality of life that reflects the efficiency of work in society, serves as a source of national wealth, and is a factor in overcoming social and economic crises. The current state of the quality of life of the population needs a significant adjustment since the destructive consequences of the reforms carried out in the early 90 s contributed not only to a significant differentiation of the population, a decrease in the quality of life of a significant proportion of the country's residents but also to the emergence of such a category as poverty. The problem is further complicated by the fact that the social and territorial differentiation of the population has been increasing in recent years. Effective quality of life monitoring system is required to identify these problems promptly.

Keywords: Quality of life. The standard of living. Population. Indicator. Assessment.
\end{abstract}

\section{RESUMO}

A modernização sistemática da economia nacional realizada nos últimos 20-25 anos contribuiu para a formação de novas condições socioeconômicas em que o principal critério para o 
desenvolvimento econômico do país é a alta qualidade de vida da população. É a qualidade de vida que reflete a eficiência do trabalho na sociedade, serve como fonte de riqueza nacional e é fator de superação de crises sociais e econômicas. O estado atual da qualidade de vida da população necessita de um ajuste significativo, pois as consequências destrutivas das reformas realizadas no início dos anos 90 contribuíram não só para uma diferenciação significativa da população, uma diminuição da qualidade de vida de uma proporção significativa dos residentes do país, mas também à emergência de uma categoria como a pobreza. O problema se complica ainda mais pelo fato de que a diferenciação social e territorial da população vem aumentando nos últimos anos. É necessário um sistema eficaz de monitoramento da qualidade de vida para identificar esses problemas prontamente.

Palavras-chave: Qualidade de vida. O padrão de vida. População. Indicador. Avaliação.

\section{RESUMEN}

La modernización sistemática de la economía nacional llevada a cabo en los últimos 20 a 25 años ha contribuido a la formación de nuevas condiciones socioeconómicas en las que el principal criterio para el desarrollo económico del país es la alta calidad de vida de la población. Es la calidad de vida que refleja la eficiencia del trabajo en la sociedad, sirve como fuente de riqueza nacional y es un factor para superar las crisis sociales y económicas. El estado actual de la calidad de vida de la población necesita un ajuste significativo ya que las consecuencias destructivas de las reformas llevadas a cabo a principios de la década de los 90 contribuyeron no solo a una importante diferenciación de la población, a una disminución de la calidad de vida de una proporción significativa de los residentes del país sino también al surgimiento de una categoría como la pobreza. El problema se complica aún más por el hecho de que la diferenciación social y territorial de la población ha ido en aumento en los últimos años. Se requiere un sistema efectivo de monitoreo de la calidad de vida para identificar estos problemas con prontitud.

Palabras clave: Calidad de vida. El estándar de vida. Población. Indicador. Evaluación.

\section{INTRODUCTION}

The content of the "quality" concept is considered multidimensional. Since quality permeates all aspects of people's lives and is one of the main factors of people's social structure and activity, its essence and content are considered from the standpoint of social psychology and philosophy, economics and cultural studies, and other sciences.

As a comprehensive assessment of the life activity of the population, the quality of life includes a system of indicators that characterize the level of realization of human needs, the degree of satisfaction in the implementation of their life plans, correlated with accepted social standards and with the resource capabilities of society. The existing methods of assessing the quality of life of the population of the territory do not fully allow diagnosing the socio-economic situation and identifying problems of poverty.

\section{METHODS}

The high socio-economic significance of studying the problems hindering the improvement of the quality of life of the population, the insufficient theoretical and methodological elaboration of the issues of assessing the quality of life of the population in the country as a whole, in its regions and municipalities separately, determined the importance and relevance of the topic.

The basis of the work consisted of theoretical developments of domestic and foreign scholars, as well as monographic works, scientific articles, statistical materials of official statistics bodies, and Internet sites. 
Systematic, analytical, comparative methods were used in the process of analysis, as well as the method of selective sociological survey.

\section{RESULTS AND DISCUSSION}

The most important conditions for the development of human potential and factors of socioeconomic development of any region are considered to be a decent level and high quality of life of the population (Avraamova, 2013; Agapova, 1993; Belyaeva, 2009).

These characteristics are historical categories that reflect the provision of citizens with material and spiritual goods at each period (Biktimirova, 2001, p. 151).

Let's characterize the "welfare of the population" concept and define the place and meaning of such categories as the level and quality of life in its structure.

The well-being of the population is directly related to the effectiveness or efficiency of the national economy (Voronin, 2016; Zherebin, 2000; Zherebin, Romanov, 2002; Kashepov et al., 2015; Kremlev, 2000; Kurchenkov, Mitrofanov, 2007).

Economic efficiency covers the problems of "input-output", "results-costs" and characterizes the relationship between the number of units of resources that are used in the production process and the resulting quantity of a product. A larger volume of the product obtained from a given amount of costs means an increase in efficiency, a smaller volume of the product from a given amount of costs indicates a decrease in efficiency (Rimashevskaya, Migranova, 2010; Roik, 2019).

The criterion of efficiency is a methodological approach to its measurement, taking into account the fulfillment of the main socio-economic goals. It gives a qualitative characteristic of the effectiveness of production. The efficiency indicator characterizes its quantitative side.

Economic and social efficiency or production-economic and socio-economic one are distinguished.

Socio-economic efficiency characterizes the level of satisfaction with social needs. Indicators of social efficiency are consumption of products per capita, the amount of income, wages, provision of public services in education, healthcare, cultural, and other social needs. Economic and social efficiency interact and condition each other, characterizing the economic and social progress of society (Roshchina, 2007; Romanov, Yarskaya-Smirnova, 2008; Ossoshanskii, 2016; Rucheva, Kadnikova, 2016).

There are two sides to human development: the formation of physiological needs (food, housing, improving health and professional skills) and the benefits that a person can extract for productive activities and active work, cultural and social life, leisure. Based on this, the "quality of life" concept is much broader and contains, in addition to material needs, needs that do not have direct economic expression. For example, environmental cleanliness, habitat safety, human relationships, psychological comfort, cultural values (Smirnov, Sidorina, 2017; Smirnykh, 2011; Sokolova, 2011; Turkina, 2007).

The choice of the quality of life indicator in the form of the resulting indicator is fully consistent with Article 7 of the Constitution of the Russian Federation and the provisions of Convention 117, which are fundamental in the development of state social policy.

The category of quality of life was introduced into scientific circulation in the 1960s in connection with attempts by foreign researchers to model the trajectories of industrial development.

The very concept of "quality of life" arose in the same years. It is believed that this term first appeared in the work of the economist J. Galbraith "The Affluent Society" and became widely used in American propaganda. The book "The American Way of Life", which has the highest "quality" in the world, served as a kind of signboard for "The Affluent Society", and although the possibility of solving modern social problems was assumed here, this concept did not have a clear scientific content. The level and quality of life are difficult and diverse categories. There are many different 
theoretical approaches and interpretations of these definitions. The quality of life was meant as all the benefits that can be provided to the consumer by a "developed industrial society", a "society of managers", where supposedly not individual interest prevails, but science and organization.

S.A. Ayvazyan was a prominent representative of the Russian school of Labor Economics and assessment of the life of the population, according to which the concepts of quality, level, and lifestyle are interpreted as follows:

The standard of living is the degree of satisfaction of the cultural and material needs of the population, which determines the well-being of people.

The quality of life is a set of environmental, social, industrial and technological, natural and climatic, political and legal, institutional, and organizational conditions in which people carry out their daily activities.

Lifestyle - the target life attitudes, including ideology (religion) of the country's population, stemming from traditions, the history of the people, including legal traditions, the organization of life, family relations, forming models of social behavior (determines the attitude to the profession, work, education, other agents, government and decisions, the quality of human potential and its effectiveness, labor results, and productivity).

The "standard of living" term was introduced by the UN in 1961. There is no unambiguous definition of the category "standard of living of the population" in the economic literature, and therefore the question of the list of indicators necessary for its adequate statistical characteristics is also debatable.

Most often, the standard of living refers to the degree to which the population is provided with the necessary material and non-material goods and services, the level of their consumption achieved, and the degree to which people's needs for these goods are met.

The standard of living is defined, first of all, as a set of goods and services available to an individual, a family, or a social group of the population. Therewith, one of the most important indicators of the standard of living, as a rule, is the indicator of household income, which determines their ability to purchase goods, services, and various assets. The income is used to finance consumer spending or be used to finance the purchase of financial assets and property by the population, the possession of which also affects the standard of living (Tserkasevich, 2015; 2017; Shishkin, 2015; Shpotov, 2015).

The standard of living is characterized by the degree of satisfaction of the material, social and cultural needs of the population. The indicator of the standard of living depends both on the level of the population's needs for goods, and on the quantity and quality of goods and services provided to the population.

In a broad sense, the "standard of living" determines the degree and structure of consumption, the circumstances of work, the satisfaction of socio-cultural needs, the level of development of the service sector, the structure and amount of free and off-duty time, the degree of environmental safety. The standard of living in the narrow sense is the amount of real income that determines the size and structure of the actual consumption of final goods and services.

A.S. Akhremenko interprets the standard of living as a complex of living conditions (leisure, work, life) of the population, which correspond to the achieved level of economic development. This complex is considered a generalizing feature of the financial situation of the population and is used in marketing activities when identifying probable demand.

According to L.V. Klimkina, the standard of living is the degree of satisfaction of the spiritual, material, and social needs of citizens. The standard of living depends on the amount of monetary income of the family. Based on this, the main indicator of the material security of the population is considered to be the total income, which includes all types of cash receipts, as well as the cost of inkind receipts from personal subsidiary farming aimed at personal consumption. 
E.V. Gorshenina believes that the standard of living is an indicator that reflects the well-being of the population and is focused on calculating the incomes of citizens and the degree of satisfaction with basic needs. In comparison with it, the quality of life is the broadest indicator, which includes an assessment of well-being among other criteria of quality of life but also takes into account several indicators of satisfaction of various kinds of needs.

The main purpose of studying the standard of living is to identify patterns of formation of the well-being of the population. In particular, the following factors should be taken into account: a comprehensive analysis of the dynamics, structure, and rate of change in the characteristics of the standard of living; the separation of different groups of the population by consumption and income; analysis of the impact of different socio-economic conditions on the level change.

The analysis of the degree of satisfaction of the needs of the population in material goods and various services in comparison with the rational norms of their consumption and the creation of generalizing characteristics of the standard of living on this basis is of great importance. The standard of living reflects in detail the social differences of individual groups of the population. Therefore, it is worth considering the standard of living of different social groups and strata of the population, families, and individuals following Figure 1.

The standard of living depends on the actual consumption of material and spiritual goods and the development of needs.

The level of consumption is a feature of consumption that depends on the number of consumers. There are three levels of consumption:

- individual - on which the consumption of each person is carried out;

- collective - where the consumption of collectives takes place;

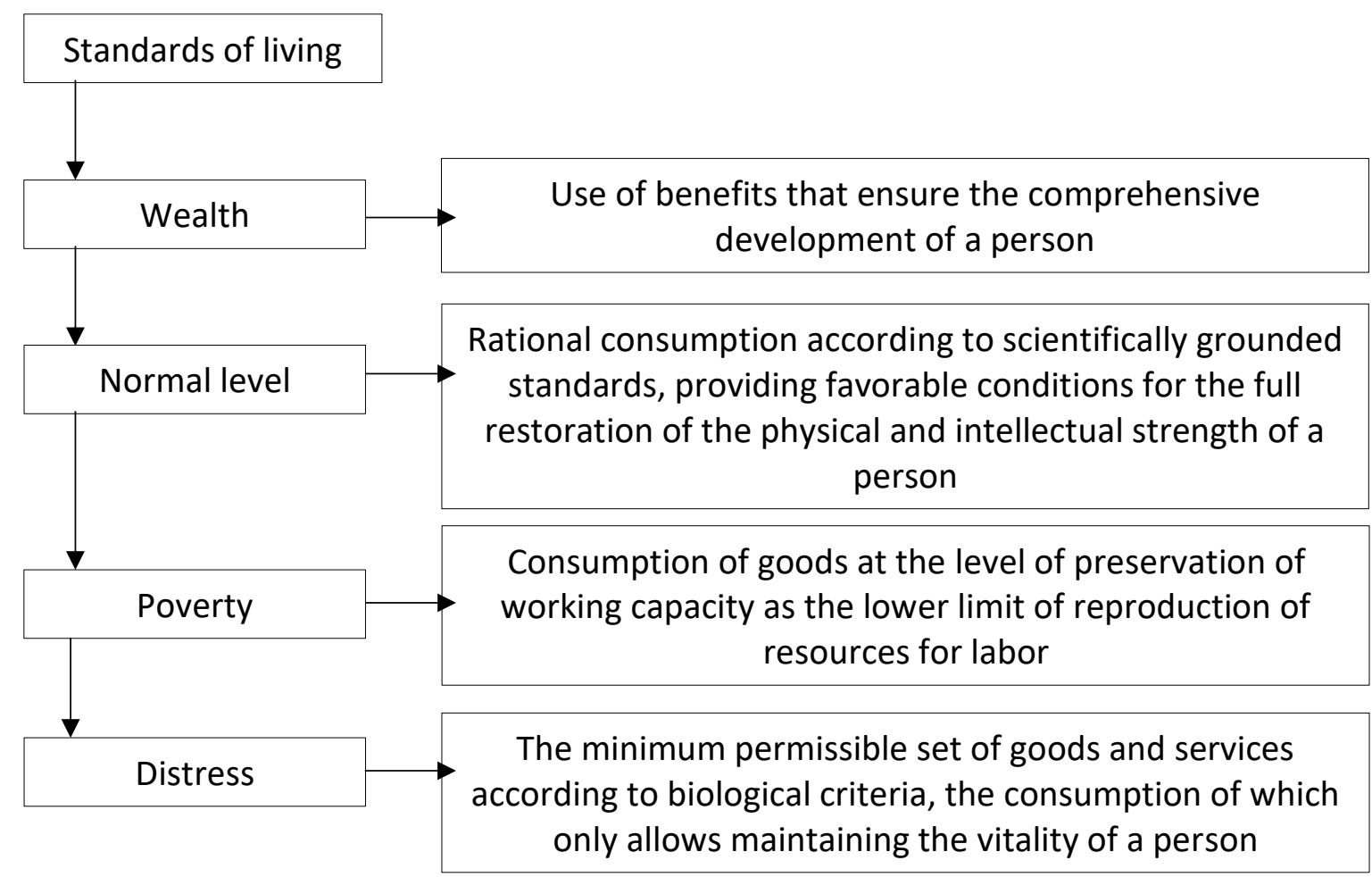

Figure 1. Living standards of the population

- public - related to the consumer interests of all people of the country (state). These are policing, security, defense, management, education, science, and external relations. Each of us needs them, but no one individually can satisfy them.

All statistical aggregates are studied to obtain the whole set of characteristics according to the standard of living: 
- the general population;

- individual social and professional groups;

- households with different incomes.

Determining the standard of living is a complex and ambiguous process. Since, on the one hand, it depends on the composition and magnitude of the needs of society, and on the other, it is limited by the possibilities to meet them, again based on various factors that determine the economic, political and social situation in the country. These include the efficiency of production and services, the state of scientific and technological progress, the cultural and educational level of the population, national characteristics, etc. (Tserkasevich, 2015).

Thus, the "standard of living" concept in its modern interpretation is quite capacious, which covers all aspects of human activity, gives an idea of the well-being of society as a whole and its members in particular.

If the standard of living is traditionally understood as a set of living standards of a predominantly material nature, then the quality of life is characterized by the degree of achievement of the highest values of human existence, both in personal and social aspects. They include moral and psychological qualities, the level of education and culture, health, working and living conditions, recreation, the degree of comfort of economic conditions, the level of needs and the degree of their satisfaction, etc. Quantifiable material components are also subjected to qualitative assessments according to the criteria of compliance with international standards.

Many authors interpret the "quality of life" and "standard of living" concepts in different ways. Everyone defines their indicators and criteria for evaluating and measuring this characteristic of the population.

J. Galbraith stated that in economically developed countries, material needs are met at the necessary level and therefore the demand for consumer goods will not increase significantly with an increase in the volume of material production. Therefore, non-material needs should be in the foreground. According to his judgments, the means of weakening the contradictions of capitalism are considered to be the resumption of the disturbed balance, which can be achieved with the help of investments that contribute to improving the "quality of life", ensuring environmental protection, qualitative changes in material production and the development of non-material services.

The quality of life is a systemic concept that is determined by the unity of its parts: the person himself/herself (as a biological and spiritual being), his/her living conditions, and the circumstances in which it takes place. It follows that the list of characteristics of the quality of life should include both objective indicators of the person (society), his/her life activity and living conditions, and subjective evaluation characteristics that reflect the location of the subject to the realities of his/her life.

Quality of life - the degree of satisfaction of the needs of the population in comparison with the accepted norms.

The United Nations, summarizing the characteristic features of national concepts of living standards in different countries of the world, points out the common essential components of these concepts: health, food consumption, education, employment, and labor organization, living amenities, social security, clothing, rest and free time, human rights.

The quality of life in modern concepts of quality abroad is understood as a complex characteristic of socio-economic, political, cultural, ideological, environmental factors and conditions of existence of the individual, the position of a person in society.

The quality of life of society, in particular, involves an assessment of a set of conditions and characteristics of life in society, based on the degree of satisfaction with these conditions and characteristics. Thus, both the totality of life characteristics (living conditions, relationships, income, values, goals, profession, social status, etc.) and the attitude in society to these characteristics determine the quality of life. 
This suggests that the criteria for evaluating this category are scientifically based consumption standards of the population. The ratio of actual satisfaction of needs with the developed standards indicates the degree of satisfaction of the needs of individuals, their groups, and society as a whole. If the degree of satisfaction of a particular need is small, this indicates an unfavorable situation in a particular sector of the economy.

The special importance of modern approaches to the definition of the concept of quality of life has separately existing and interrelated subjective and objective components in assessing the quality of life. Therewith, the objective side is determined by normative and statistical characteristics that allow judging the degree of satisfaction of reasonable needs and interests of people.

Each person has his/her scale of preferences, as a result of which the same degree of satisfaction of a particular need is evaluated differently by different individuals. Therefore, it is not possible to determine people's satisfaction with the quality of their life at this stage of the development of human civilization.

Finally, the quality of life, combining many aspects of the standard of living, emphasizes qualitative certainty in them. Thus, speaking about nutrition as one of the most important components in meeting needs, it is impossible to limit the analysis to the number of kilograms of consumed products or the caloric content of the diet, it is also necessary to pay attention to such qualities of nutrition as regularity, diversity, etc.

The quality of life is characterized by the degree of satisfaction of human needs, determined concerning the relevant norms, customs, and traditions, as well as concerning the level of personal claims. In other words, the quality of life is a set of characteristics reflecting the material, social, physical, and cultural well-being of the population.

This indicator includes, in addition to the standard of living, working conditions, and safety, cultural level, physical development. According to other economists, the quality of life includes the level of consumption of material goods and services, the satisfaction of spiritual needs, health, life expectancy, environmental conditions, security of citizens, personal freedom.

The quality of life determines the conditions of human existence: provision with material goods (food, clothing, housing); security; availability of medical care; opportunities for education and development of abilities; the state of the natural environment; social relations in society, including freedom of expression and the influence of citizens on political decisions.

Some researchers propose to consider the quality of life from the standpoint of a systematic approach, as an integral system, which is expressed through the interrelation of its components: the quality of culture, the quality of health, and the quality of the environment. The organization of the integrity of the system assumes a natural division into components that can be considered as subsystems following Figure 2 .

Standard of living

$$
\text { Quality of culture Spirituality } \begin{gathered}
\text { Quality of } \\
\text { education, safety, } \\
\text { ecology }
\end{gathered}
$$

Habitat quality

Figure 2. A model of the quality of life as an integral system 
The quality of life, as a comprehensive analysis of people's life activity, assumes the concept of indicators that characterize the level of realization of a person's needs, the level of satisfaction with the implementation of his/her life plans, correlated with minimum social standards and with the resource capabilities of society.

The quality of life of the population is not limited only to their standard of living, even though the indicators of the standard of living have a significant impact on the feeling of social comfort. It is determined by the signs of satisfaction of the needs of the population under certain social circumstances, supplemented by the confidence that they managed to preserve and not endanger their mental and physical integrity, opportunities for creativity, and personal freedom. Quality of life indicators can serve both as a goal of social development and as a condition for it. No actions of the state should lead to a deterioration in the quality of life beyond the threshold values.

The "quality of life" concept has taken a stable position in scientific circulation over the past time, along with the concepts of lifestyle and standard of living. The interest in the problems of quality of life can be traced, first of all, in the most prosperous settlements, the authorities of which is concerned not so much with the problems of social protection and support of poor households and segments of the population, as with the problems of sustainable social development (in which each subsequent generation of people is in no worse living conditions than the previous one).

The high quality of life of an individual is considered when he/she has:

- a high life potential;

- the concept of interests, goals, values, and behavioral styles has been formed;

- basic psychological and physiological needs are satisfied;

- secondary needs (personal growth and creative activity, as well as conditions for their implementation) are a priority;

- conscious life activity is carried out with stage and final achievements, positive emotions and feelings prevail.

The quality of life is an extensive complex of human life conditions following Figure 3.

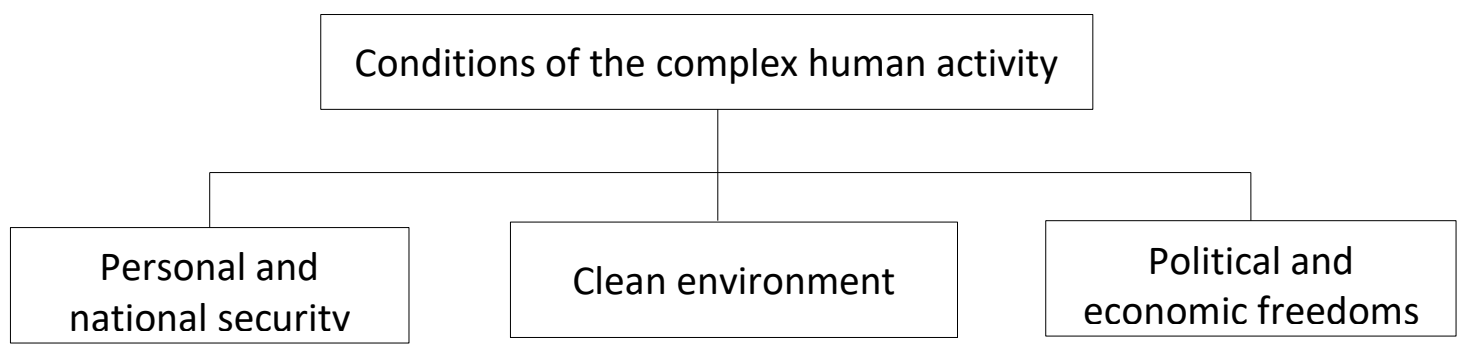

Figure 3. Conditions of the human life complex

The high quality of life of society is considered when:

- the basic needs of all members of society are met at a level not lower than the minimum social standard, that is, there is no poverty;

- social, entrepreneurial, political, industrial, scientific, cultural, and economic activities are carried out in all areas of socio-economic development with milestone achievements that contribute to the quality of life of the population;

- the absolute majority of people are satisfied with their state and what is happening in it, feel a sense of pride for it.

Improving the quality of life - increasing the ability of the population to regulate their problems, achieve personal success and individual happiness.

There are certain areas of the quality of life of the population. There are eight areas of quality of life following Figure 4. 
To describe the essence of the quality of life as a socio-economic category, it is necessary to highlight its distinctive feature: the quality of life is a sociological category that covers all spheres of society since they all contain people's lives and their quality.

As already noted, the quality of life has two sides: objective and subjective.

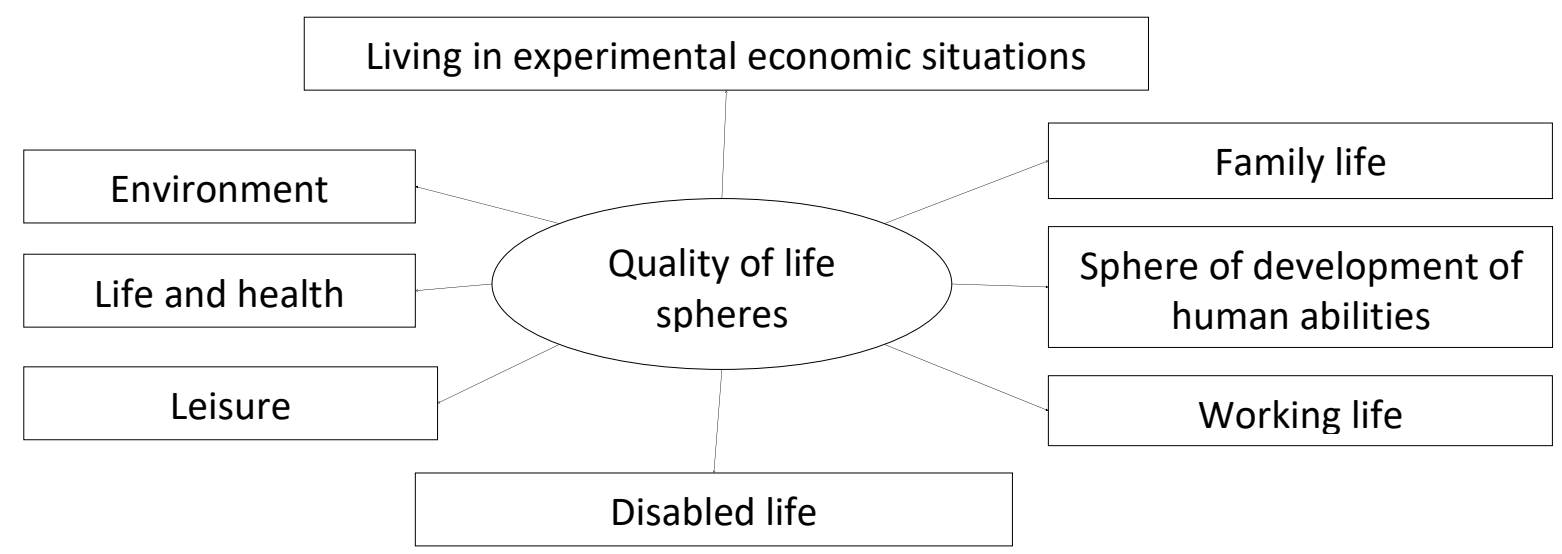

Figure 4. Areas of quality of life of the population

The criteria for an objective assessment of the quality of life are scientific standards of people's interests and needs, according to which one can objectively judge the degree of satisfaction of these needs and interests. On the other hand, people's needs and interests are individual and only the subjects themselves can assess the degree of their satisfaction.

The quality of life reflects the degree of development and completeness of satisfaction of the entire system of people's needs and interests, which are manifested both in various types of activities and in the perception of life itself. The standard of living includes the results, conditions, and nature of work, ethnographic, ecological and demographic aspects of people's existence.

Economists pay special attention to the problem of poverty considering the level and quality of life. Poverty is a state of constant lack of the necessary resources to ensure a satisfactory lifestyle acceptable in this particular case. The existence of the problem of poverty is since monetary incomes are distributed unevenly among people, which is typical for all countries of the world.

There are about two hundred countries with different levels of economic development in the modern world. The division of the world economy is uneven. The largest concentration of the share of production of goods and services is concentrated in the countries of North America, Western Europe, and the Pacific basin.

Such indicator as the human development index is used to analyze the trends in the development of the economy within the country, as well as to identify the relationship, distinctive and similar features between countries, to determine the "leading" and "lagging" countries.

The Human Development Index (HDI) is an integrated indicator used for cross-country comparisons and calculated annually by the United Nations Development Programme (UNDP) based on the following components of human development: life expectancy at birth, the average duration of education, and expected duration of education, gross domestic product per capita (in US dollars at purchasing power parity).

The index was developed in 1990 by Pakistani economist Mahbub ul Haq and Indian economist Amartya Sen.

The Human Development Index is based on the concept of Human Development, introduced into international political and scientific circulation by the United Nations as part of the preparation of world human development reports published by UNDP since 1990.

The concept formulates a fundamental idea: the highest goal of economic and social development is to expand opportunities for each person to realize their abilities and aspirations, to lead a healthy, full-fledged, creative life. The personality, the individual (and not the "human factor" 
or "human material") are considered in this concept not only as of the most important factor of human development but also as the main consumer of its results and achievements.

The concept of human potential development does not contradict traditional theories of economic development, but focuses economic development not only on increasing the rate of economic growth, but also on human development, overcoming their limitations, and a certain separation from social relations.

Even though modern research on the quality of life is multidirectional, the emergence of the concept of human potential gave a new impetus to the development of the concept of quality of life and predetermined the direction of research for several years to come. Although it should be noted that this concept has recently been criticized.

The index is published within the framework of the UN Development Program in Human Development Reports among 187 countries and has been published by the UN in the annual Human Development Report since 1990.

The latest Human Development Report from The United Nations Development Program, compiled based on the estimated data of 2019 and published on December 15, 2020. The list includes 187 UN member States out of 193, as well as Hong Kong (Special adm. area PRC) and Palestine. Six data member states.

UN countries (North Korea, Monaco, Nauru, San Marino, Somalia, and Tuvalu) are divided into four large categories based on their HDI: very high, high, medium, and low levels of human development.

The HDI for Russia in 2020 was 0.824 . The country ranks 52nd among 189 countries in the world and remains in the group with a very high level of human development. Since 1990, the HDI value has increased from 0.735 to 0.824 , an increase of $12.1 \%$.

With an average life expectancy of 72.6 years, Russians study for more than 15 years, and the gross per capita income adjusted for purchasing power parity is 26,157 thousand US dollars.

Thus, since 1990, life expectancy in the Russian Federation has increased by 4.5 years, the duration of education - by 3 years, and $\mathrm{GNI}$ - by $21.6 \%$.

Even though GNI in Russia is higher than in some countries of Europe and Central Asia $(17,939$ US dollars), it is significantly lower than in countries with a very high human development index (44,566 thousand US dollars). The authors of the report compare Russia with other post-Soviet countries by this indicator. Thus, the GNI of Kazakhstan is 22,857 US dollars, Belarus $-18,546$ US dollars, Ukraine - 13,216 US dollars.

As for the gender development index, Russia ranks 50th out of 162 countries. Women occupy $34.9 \%$ of seats in Parliament in the country. For comparison, in Kazakhstan $-22.1 \%$, in Ukraine $20.5 \%$, in Belarus - 34.9\%.

Eighty-seven point 2 tenths \% of adult Russians have at least secondary education $195.7 \%$ of men have higher education). Currently, the share of working women in the country does not exceed $55 \%$, while more than $70 \%$ of men work.

In addition, this year two new environmental indicators are used in the calculation of HDI: the amount of carbon dioxide emissions and the material footprint (the number of natural resources used for the production of goods and services). According to the latest data, there are 11.7 tons of carbon dioxide emissions per capita for every adult. If we recalculate the HDI for the country, taking into account the negative impact that this development has on the environment, it will decrease by $5.1 \%$.

According to the UN, HDI in the world has increased by an average of $0.6 \%$ per year over the past five years. Experts note that with such an indicator, it is impossible to maintain GDP growth, even if there is good technology growth and sufficient capital in the market.

\section{CONCLUSIONS}


Scholars have been constantly developing social indicators of the quality of life in recent years, considering aspects of determining the image and standard of living, their relationship. However, there is still no single approach to determining the quality and standard of living.

The standard of living is most often considered in two aspects: in the broad and narrow sense of the word. In a narrow sense, "standard of living" is the achieved level of consumption of material goods and services by the population. In a broad sense, the "standard of living" includes the whole complex of socio-economic conditions of society. The quality of life is most often determined in the aspect of the totality of certain life values that characterize the types of activities, conditions of existence, the structure of needs, the satisfaction of an individual with life, social relations, and the state of the environment.

In the Russian Federation, statistics are represented by a system of subjects of statistical accounting: statistical agencies, economic services of firms, banks, exchanges, management bodies, ministries, and departments. The central link in the system of state statistics bodies is Rosstat with departmental subordination to the Ministry of Economic Development of the Russian Federation.

Rosstat exercises the authority to generate official statistical information independently and through the territorial bodies of state statistics in the subjects of the Russian Federation.

The range of social problems that local authorities should solve is quite wide. This includes health issues, secondary and vocational education, the field of municipal transport, the activities of housing and communal services of the city.

Today, when the entire social sphere is under the jurisdiction of the city administration, it is necessary to put into practice new approaches in determining the priority tasks of concern to the population, to approach the solution of social problems of urban entities using modern technologies based on scientific developments.

Authors' Contributions: Morozova, L.: conception and design, acquisition of data, analysis and interpretation of data, drafting the article, critical review of important intellectual content. Karpova, E.: conception and design, acquisition of data, analysis and interpretation of data, drafting the article, critical review of important intellectual content. Kolosova, O.: conception and design, acquisition of data, analysis and interpretation of data, drafting the article, critical review of important intellectual content. Kulikova, O.: conception and design, acquisition of data, analysis and interpretation of data, drafting the article, critical review of important intellectual content. Suvorova, T.: conception and design, acquisition of data, analysis and interpretation of data, drafting the article, critical review of important intellectual content. All authors have read and approved the final version of the manuscript".

Ethics Approval: Not applicable.

Acknowledgments: Not applicable.

\section{REFERENCES}

Agapova, T. (1993). Prozhitochnyi minimum v sisteme sotsialnykh otnoshenii [Living wage in the system of social relations]. Probl. teorii i praktiki upravl, 5, 111-116.

Avraamova, E.M. (2013). Rost materialnoi obespechennosti naseleniya: blagodarya chemu i s kakimi posledstviyami? [Growth in the material security of the population: due to what and with what consequences?]. Obshchestv. nauki i sovremennost, 1, 5-15.

Belyaeva, L.A. (2009). Uroven i kachestvo zhizni. Problemy izmereniya i interpretatsii [The level and quality of life. Measurement and interpretation problems]. Sotsiol. issled, 1, 33-42.

Biktimirova, Z.Z. (2001). Prognoz urovnya zhizni naseleniya Rossii v 2001-2010 gg. [Forecast of the standard of living of the population of Russia in 2001-2010]. EKO, 7, 56-67.

Kashepov, A.V., Sulashkin, S.S., Malchinov, A.S. (2015). Rynok truda: problemy i resheniya: Monografiya [Labor market: problems and solutions: Monograph]. Moscow: Nauchnyi ekspert.

Kremlev, N.D. (2000). Problemy otsenki urovnya zhizni naseleniya [Problems of assessing the living standards of the population]. Vopr. statistiki, 8, 18-23. 
Kurchenkov, V.V., Mitrofanov, I.V. (2007). Uroven zhizni naseleniya Yuzhnogo Federalnogo okruga [Living standard of the population of the Southern Federal District]. Uroven zhizni naseleniya regionov Rossii, 2, 50-60.

Ossoshanskii, A.I. (2016). Otsenka kachestva zhizni naseleniya: obzor metodologicheskikh podkhodov [Assessment of the quality of life of the population: a review of methodological approaches]. Molodoi uchenyi, 11, 440-445. Retrieved from: https://moluch.ru/archive/58/8095/

Rimashevskaya, N.M., Migranova L.A. (2010). Vliyanie finansovogo krizisa na uroven zhizni naseleniya Rossii [The impact of the financial crisis on the standard of living of the population of Russia]. Uroven zhizni naseleniya regionov Rossii, 5, 71-85.

Roik, V.D. (2019). Sotsialnaya zashchita otdelnykh kategorii grazhdan. Kachestvo zhizni pozhilogo naseleniya: uchebnoe posobie dlya srednego professionalnogo obrazovaniya [Social protection of certain categories of citizens. Quality of life of the elderly population: a textbook for secondary vocational education]. Moscow: Izdatelstvo Urait. Retrieved from: https://urait.ru/bcode/442264

Romanov, P., Yarskaya-Smirnova, E. (2008). Sotsialnaya politika v sovremennoi Rossii: reformy i povsednevnost: Monografiya [Social policy in modern Russia: reforms and everyday life: Monograph]. Moscow: Variant.

Roshchina, T.G. (2007). Trudovaya migratsiya kak faktor povysheniya urovnya zhizni naseleniya malykh gorodov Rossii [Labor migration as a factor in improving the living standards of the population of small towns in Russia]. Vestn. Ros. akad. nauk, 77(9), 827-830.

Rucheva, D.V., Kadnikova, O.V. (2016). Problemy povysheniya kachestva zhizni naseleniya Rossii v usloviyakh krizisa [Problems of improving the quality of life of the population of Russia during the crisis]. Ekonomika i menedzhment innovatsionnykh tekhnologii, 8. Retieved from: https://ekonomika.snauka.ru/2016/08/12392

Shishkin, S.V. (2015). Ekonomika sotsialnoi sfery: Uch. posobie [Social Economics: A Study Guide]. Moscow: State University Higher School of Economics.

Shpotov, B.M. (2015). Genri Ford: Zhizn i biznes [Henry Ford: Life and Business]. Moscow: KDU.

Smirnov, S.N., Sidorina, T.Yu. (2017). Sotsialnaya politika [Social politics]. Moscow: Publishing House of HSE.

Smirnykh, L.I. (2011). Nestandartnye trudovye dogovory i uroven zhizni rabotnikov [Non-standard employment contracts and the standard of living of workers]. Uroven zhizni naseleniya regionov Rossii, 6, 65-75.

Sokolova, G. (2011). Problemy vzaimosvyazi urovnya i kachestva zhizni v khode stanovleniya postindustrialnogo obshchestva [Problems of the relationship between the level and quality of life during the formation of a postindustrial society]. Obshchestvo i ekonomika, 7, 65-81;

Tserkasevich, L.V. (2015). Sotsialnaya politika i strategiya ee realizatsii v stranakh Evropeiskogo Soyuza [Social policy and strategy for its implementation in the countries of the European Union]. SPb.: Publishing House SPbGUEF.

Tserkasevich, L.V. (2017). Novye tendentsii v sotsialnoi politike stran ES: Uch. posobie [New Trends in Social Policy of EU Countries: A Study Guide]. SPb: Publishing House SPbGUEF.

Turkina, N.G. (2007). Kachestvo i uroven zhizni selskogo naseleniya Irkutskoi oblasti [Quality and standard of living of the rural population of the Irkutsk region]. Geografiya i prirod. resursy, 4, 103-109.

Voronin, A.A. (2016). Munitsipalnoe khozyaistvovanie i upravlenie: problemy teorii i praktiki [Municipal economy and management: problems of theory and practice]. Moscow: Finance and Statistics.

Zherebin, V.M. (2000). Uroven zhizni naseleniya - kak on ponimaetsya segodnya [The standard of living of the population - as it is understood today]. Vopr. statistiki, 8, 3-11.

Zherebin, V.M., Romanov, A.N. (2002). Uroven zhizni naseleniya: Osnovnye kategorii, kharakteristiki i metody otsenki [Living standards of the population: Main categories, characteristics and assessment methods]. Moscow: Unity.

Received: 13 August 2021 | Accepted: 22 November 2021 | Published: 31 January 2022 